Ewa Litwin

STOWARZYSZENiE Filozofów Krajów SŁowiańSKich e-mail: evaevita@op.pl

(iD) https://orcid.org/0000-0003-2127-5305

\title{
Narodziny polskiej myśli narodowej - z perspektywy włoskiej
}

\section{Daniele Stasi: Le origini del nazionalismo in Polonia. Milano 2018, 146 s.}

\section{Abstract}

\section{The Birth of Polish National Thought from an Italian Perspective}

The article aims to present the work of Daniele Stasi regarding the birth of Polish nationalism. The book was published in 2018 in Italian by FrancoAngeli as Le origini del nazionalismo in Polonia. The author puts forward some theses concerning the process of national building in the period preceding the partitions of Poland, which represents terminus a quo for his analysis of the ideologies related to the national issue and rebirth of Polish state. Terminus ad quem of the author's analysis is Roman Dmowski's Myśli nowoczesnego Polaka. Based on rich and interdisciplinary literature, Stasi's work aims to fill the gap in Italian historiography, related to the birth of Polish nationalism.

Key words: national building, modernization in Poland, mass movement, Roman Dmowski

Slowa kluczowe: nacjonalizm, modernizacja Polski, ruch masowy, Roman Dmowski 
Książka Daniele Stasiego Le origini del nazionalismo in Polonia wypełnia lukę w badaniach poświęconych tematom europejskiej historiografii - zwłaszcza tych, odnoszących się do kwestii początków polskiego nacjonalizmu. Dodajmy od razu: w uniwersyteckiej nauce we Włoszech. Wszak do tamtego czytelnika książka jest kierowana w pierwszej kolejności.

Temat monografii od wielu lat jakże aktualny, budzi również zainteresowania włoskich badaczy historii doktryn politycznych w Europie Środkowej i Wschodniej. Daniele Stasi, z pochodzenia Włoch, jest od dwunastu lat wykładowcą Uniwersytetu Rzeszowskiego, gdzie prowadzi kursy z filozofii polityki, a od dwóch lat jest również pracownikiem Uniwersytetu w Foggi, zajmującym się historią doktryn politycznych. Autor, w swojej publikacji, poszukuje korzeni nurtu nacjonalistycznego w epokach poprzedzających wiek XX, przygląda się też kształtowaniu frakcji Narodowej Demokracji (Endecji) oraz bada jej ideologię, a także składowe programu. Książka składa się z pięciu rozdziałów. W pierwszych dwóch częściach autor zwraca uwagę na pojęcia nacji i nacjonalizmu w odniesieniu do konkretnej formy państwowości: Rzeczpospolitej Obojga Narodów. Profesor Stasi w pierwszym rozdziale analizuje (Nazione nobiliare e semiperiferica) relacje pomiędzy procesem budowania państwowości a ideą nacji. Opierając się na bogatej literaturze interdyscyplinarnej, autor przedstawia różnice, sformułowane przez Friedricha Meineckego, pomiędzy nacją kulturową a nacją terytorialną (nazione culturale e nazione territoriale). Według słynnej definicji Meineckego nacja kulturowa jest, w przeciwieństwie do nacji terytorialnej, pozbawiona państwowości. Autor wyjaśnia, iż wspólny punkt wielu polskich nurtów politycznych w XIX wieku polegał na wypracowaniu strategii i starań, aby nie przekształcić nacji kulturowej w nację terytorialną. Inaczej mówiąc, kwestia odzyskania suwerenności wywierała presję na koncepcje polityczne w Polsce, rzecz jasna, również na kategorię nacjonalizmu.

Daniele Stasi definiuje status polskiej nacji jako półperyferyjnej, odwołując się do zróżnicowania wypracowanego przez Immanuela Wallersteina. Owe argumentacje odnoszą się do relacji ekonomicznych, kulturowych, które Rzeczpospolita Obojga Narodów, a potem Polska Nacja Kulturalna zawierały z innymi państwami. Rzeczpospolita Obojga Narodów - ze wspólnymi monarchą, herbem, walutą, polityką zagraniczną i obronną - zachowała odrębny skarb, urzędy, wojsko i sądownictwo. Analiza autora wskazuje wyraźnie na zacofanie instytucji politycznych, systemu gospodarczego i prawa przed trzecim rozbiorem Polski (1795). Autor ilustruje jeden z podstawowych aspektów tej formy polityczności, mianowicie ideologię sarmatyzmu, która zasadniczo ugruntowała hegemonię szlachty nad innymi stanami społeczeństwa polskiego (Stasi 2018: 17). Jak zauważył Jan Sowa, szlachta uznawała siebie za „grupę etnicznie i narodowo odmienną od chłopów i mieszczaństwa, przyznając sobie jedyne prawo do kształtowania narodowości polskiej" (Sowa 2011: 12-13).

212

Fabrica Litterarum Polono-Italica | 2020, nr 1 (2) 
Autor próbuje określić konfigurację geopolityczną, w której znalazła się Polska w XIX wieku, oraz trzy podstawowe aspekty tej sytuacji: zacofanie kulturowe i polityczne polskiej społeczności, rozbiór oraz pragnienie odzyskania niepodległości. W kolejnym rozdziale autor opisuje myśl narodową obecną w reformach kulturowych oraz politycznych w epoce oświecenia. Daniele Stasi odnosi się do jednej z najważniejszych reform, jaką było wprowadzenie Konstytucji (3 maja 1791 roku). Autor przytacza słowa Andrzeja Walickiego:

Konstytucja przewidywała radykalną reorganizację władzy, między innymi dziedziczenie monarchii, owoc rodzącej się nowej siły między burżuazją a królem. Wraz z Konstytucją zostało zniesione liberum veto, któremu głośno się sprzeciwiał jeden z wybitnych reformatorów, Hugo Kołłątaj, a w poprzednim okresie u schyłku Rzeczpospolitej sam Poniatowski... (Walicki 2009: 441).

Celem Konstytucji Polski, uchwalonej w Europie jako pierwsza, było zapoczątkować „polonizację” mniejszości narodowych. Stasi konstatuje: „Państwo miało reprezentować cały naród, a nie identyfikować się tylko i wyłącznie ze szlachtą”. Zapisana w Konstytucji, jako nowy podmiot polityczny, formująca się klasa średnia, miała być zdolna do budowy rodzącego się nowoczesnego państwa. Niestety, nowy nurt polityczny, modernizujący kraj i mający swe korzenie w oświeceniu, nie był na tyle spójny, aby stawić czoła atakom obcych mocarstw (rosyjskiego, austriackiego oraz pruskiego), co w konsekwencji doprowadziło do trzeciego rozbioru Polski w 1795 roku, po zaledwie czterech latach panowania ładu konstytucyjnego.

Po trzecim rozbiorze Polski trud budowania podstaw ruchu na rzecz niepodległości przypadł tzw. drobnej szlachcie, której uosobieniem stał się Tadeusz Kościuszko. Jak pisze autor:

Koncepcja Kościuszki przyczyniła się w pewnej mierze do powrotu idei, w porównaniu do propozycji reformatorskiego ruchu oświecenia, jako że utrwalała pluralizm kulturowy, który Kołłątaj starał się wyeliminować poprzez monopol edukacyjny ze strony państwa. Rodząca się mała burżuazja z woli oświeceniowców tworzyła społeczne podstawy dla reform. Po utracie suwerenności narodowej to właśnie „drobna szlachta” oraz chłopi współpracowali na rzecz niezależnego ruchu w przeciwieństwie do burżuazji, która skupiała się tylko i wyłącznie nad relacjami w sferze wymiany handlowej z okupantami (Stasi 2018: 40).

W drugim rozdziale autor zwraca szczególną uwagę na dziedzictwo Oświecenia w myśleniu patriotów rozdartych pomiędzy dwiema frakcjami - tymi, którzy uważali, że sposobem odzyskania niepodległości pozostaje konspiracja oraz powstanie, i tymi, którzy szukali modus vivendi z obcą władzą. Autor opisuje rolę jedynej war-

213

Fabrica Litterarum Polono-Italica | 2020, nr 1 (2) 
stwy narodowej w tym okresie - inteligencji - jej specyficzne cechy w kontekście zmian ekonomicznych i politycznych zachodzących w kraju, zwłaszcza w zaborze rosyjskim.

Druga część monografii dotyczy narodzin nacjonalizmu. Nim autor przejdzie do analizy ustrukturyzowania polskiego nurtu nacjonalistycznego, zwraca uwagę na definicję narodu opracowaną przez inny masowy nurt, ideologicznie odmienny od nacjonalizmu - socjalizm. Stasi zaznacza, iż dzieje polskiego socjalizmu od samego początku naznaczone są gorącą debatą pomiędzy zwolennikami stawiającymi pierwszeństwo odzyskania polskiej niepodległości oraz orędownikami internacjonalizmu i prymatu międzynarodowej walki klas. Autor przedstawia, mało znaną we włoskiej historiografii, postać Kazimierza Kellesa-Krauza, przytaczając przy tym słowa Leszka Kołakowskiego, który określił Kellesa-Krauza jako „najważniejszego ideologa polskiego ruchu socjalistycznego" (Kołakowski 2009: 221). Według Kellesa-Krauza w świadomości narodowej istotną rolę odgrywa nie tylko więź językowo-kulturowa, ale także samodzielny, niezawisły byt państwowy, który jest niezbędnym warunkiem rozwoju narodowego oraz drogą do transformacji socjalistycznej polskiej społeczności. Kazimierz Kelles-Krauz wskazywał na funkcjonalną współzależność języka i czynników ekonomicznych w procesie narodowotwórczym i dowodził, że koniecznym następstwem rozwoju ekonomicznego jest zdefiniowanie świadomości narodowej proletariatu, obrona narodowości przez klasę robotniczą i jej dążenie do niepodległego oraz demokratycznego państwa narodowego. Jako jeden z ideologów Polskiej Partii Socjalistycznej pierwszy podjął się rozwiązania problemów rolnictwa i poprawy bytu chłopstwa.

Ostatnie trzy rozdziały monografii Stasiego poświęcone są trzem założycielom polskiego nacjonalizmu: Janowi Ludwikowi Popławskiemu, Zygmuntowi Balickiemu i Romanowi Dmowskiemu. Popławski, nazwany przez Stasiego „Il padre spirituale del nazionalizmo" (duchowy ojciec nacjonalizmu; Stasi 2018: 65) uważał, że inteligencja nie jest przydatna z punktu widzenia reprezentowania całego narodu, a zwłaszcza tego, co możemy nazwać polskością. Popławski, pod wpływem filozofii pozytywistycznej, uznawał, iż naród potrzebuje gruntownej pracy organicznej na rzecz podniesienia własnego stanu ekonomicznego i kulturowego. Do tego celu inteligencja okaże się mało przydatna, gdyż, według Popławskiego, jest uzależniona od obcych nurtów kulturowych. W unowocześnieniu ekonomicznych i politycznych warunków życia narodowego podstawową rolę odgrywa zorganizowany nacjonalistyczny ruch polityczny, który działa na trzech obszarach byłego państwa polskiego i reprezentuje nade wszystko ludność wiejską (Popławski 2012: 3-12), autentycznego reprezentanta polskości, w odróżnieniu do bogatych i kosmopolitycznych wyższych warstw społecznych. Stasi podkreśla ideę Popławskiego, według której nie ma w Polsce „trzeciego stanu” - co można było zauważyć np. w ówczesnym francuskim społeczeństwie.

214

Fabrica Litterarum Polono-Italica | 2020, nr 1 (2) 
Słabość Polaków, według Popławskiego, wynika z braku solidnej więzi narodowej oraz z nieobecności pożądanej równości pomiędzy warstwami społecznymi. Warstwy wyższe narodu w związku z tym można scharakteryzować jako egoistyczne wobec mas ludowych. Daniele Stasi przytacza niektóre fragmenty dzieł Popławskiego, przykładowo te zawarte w artykule Demokratyzacja zasad:

Przeszłość nasza wyodrębniła zupełnie warstwy wyższe od masy narodu, pomiędzy dwoma tymi światami zerwały się wszystkie prawie nici, podtrzymujące obcowanie wzajemne. Nastąpił rozbrat całkowity, którego nie można nawet porównywać z przeciwieństwem interesów stanowych w Europie Zachodniej, gdzie różnice te przechodzą cały szereg stopniowań. Błędem jest mniemanie, że przeciwieństwo to nosi u nas wyłącznie charakter społeczno-ekonomiczny, że wielki posiadacz ziemski przeciwstawia się drobnemu: kapitalista - najemnikowi, szlachcic - chłopu. Rozdział sięga głębiej, po jednej stronie bowiem stoi cała warstwa uprzywilejowana w jakikolwiek sposób, cała inteligencja narodu - po drugiej zwarta masa ludowa, związana tylko nieświadomym poczuciem wspólności plemiennej. A więc naród pański i naród chłopski. Na jednej stronie zbierały się wszystkie światła i cienie wszystkie. Wspomnienia świetnych czynów i ofiar wielkich, wspaniałe zabytki przeszłości i relikwie troskliwie chowane, życie smutne nieraz, ale pełne świadome swego celu [...]. Druga strona zostaje dotąd w półmroku, ze swą szarą dolą, ze swą pracą niezmienną. [...] Społeczeństwo nasze robi takie wrażenie jakby z granitowego piedestału wystrzeliła w górę kolumna, cienka niezmiernie u podstawy, rozszerzająca się potem i zakończona szerokim a ciężkim kapitelem. Pomiędzy warstwą inteligentną i ludem istnieje łączność tak słaba, że lada podmuch wichru obalić ją może. To, co właściwie nazywa się u nas narodem, stanowi drobny zaledwie odsetek milionowej masy plemiennej i wyodrębnia się od niej zupełnie. Skutki tej odrębności występują obecnie już tak wyraźnie, że można je dokładnie zaznaczyć. Jałowość naszej umysłowości, nieodświeżanej dopływem nowych soków, tchórzliwość myśli, lękającej się wszelkich poglądów starszych, lękliwość uczuć, pozbawionych tego impulsu, jakie im nadaje oddziaływanie wzajemne - wszystko to następstwa owej wyłączności (Popławski 2012: 19).

Kilka stron dalej Daniele Stasi wskazuje, jak dla Popławskiego jednym z podstawowych punktów programu Ruchu Narodowego staje się postulat każący uczynić z Polaków obywateli świadomych i aktywnych w procesie odzyskiwania niepodległości. Demokratyzm Popławskiego bowiem stanowi hasło do mobilizacji członków wspólnoty.

W ostatnich rozdziałach pracy poruszony zostaje temat ogniskujący uwagę trzech ważnych dla rozwoju myśli narodowej autorów: antysemityzm. Partia socjalistyczna stanowi, według "duchowego ojca nacjonalizmu”, swoistą "frakcję antynarodową" - ponieważ w działaniach wspomnianej partii liczny udział biorą

215

Fabrica Litterarum Polono-Italica | 2020, nr 1 (2) 
Żydzi. Włoski autor przytacza ponownie fragment artykułu Popławskiego Nasz demokratyzm:

[...] ale co najmniej dziwnym byłoby żądanie od nich miłości dla tradycji narodowej, dla przeszłości, z której tylko zapamiętać mogli upokorzenie i krzywdy, dla kultury, w której wytworzeniu udziału nie brali, a tym bardziej żywego poczucia odrębności plemiennej, instynktu rasy, do której nie należą, z którą nic nie mają wspólnego. A partia socjalistyczna nie tylko wpływom nie ulega, ale z ich poglądami, uczuciami i wymaganiami liczyć się musi. W Galicji zwłaszcza jest to aż nadto widoczne i przykre, że nawet u socjalistów ujawniać się zaczyna słaby zresztą prąd antysemicki (Popławski 2012: 46).

Ten wątek został pod wieloma względami pogłębiony przez Zygmunta Balickiego, autora słynnego dzieła Egoizm narodowy wobec etyki. Dla tego myśliciela zasada walki między nacjami oraz egoizm narodowy stanowią stałe elementy relacji między wspólnotami narodowymi. Również dla Balickiego socjalizm pozostaje maskowaną ideologią Żydów. Choć Balicki opisuje socjalizm jako „dziecko wielkiej rewolucji francuskiej" (Balicki 2012: 235-242) i docenia jego rolę w rozwiązaniu problemów wynikających z organizacji kapitalistycznej społeczeństwa, sam socjalizm zdefiniuje jako cudzy nurt polityczny, który „nie ma w sobie nic polskiego”.

Wspólnota żydowska - jako element obcy w narodzie polskim - stanowi pierwotną przyczynę rozbiorów i upadku wspólnoty. Należy, według autora Egoizmu narodowego wobec etyki, przeciwstawić egoizmowi klasowemu socjalistów egoizm narodowy Polaków. Socjalizm jest w ostatecznym rozrachunku doktryną służącą tylko interesom tych, którzy dążą do rozbioru Polski, mianowicie Żydów. Socjalizm, z tego punktu widzenia, jest formą egoizmu narodowego, czyli egoizmu Żydów, któremu trzeba przedstawić egoizm Polaków.

Włoski autor analizuje dalej treści dzieł Balickiego, a przede wszystkim idee etyki narodowej. Podstawowe miejsce w tej analizie zajmuje pojęcie altruizmu oraz ideał „obywatela-żołnierza”. Balicki odrzuca altruizm jako uczucie typowe dla „słabych” i w gruncie rzeczy podważające obowiązki każdego Polaka, który musi być solidarny tylko i wyłącznie w stosunku do własnych rodaków. Altruizm na poziomie międzynarodowym bądź w odniesieniu do reprezentantów innych nacji stanowiłby „grzech” w stosunku do przedstawicieli własnego narodu. Egoizm narodowy staje się zatem conditio sine qua non idei odrodzenia narodowego.

Każdy Polak, według Balickiego, musi być gotowy umierać za naród i stać się „obywatelem-żołnierzem” (Stasi 2018: 115), kimś, kto prowadzi zdyscyplinowane życie i posiada "stalowy charakter" (Balicki 2008: 63). Wojskowy ideał obywatelstwa wyklucza organizację życia publicznego w sensie liberalnym. Balicki mocno krytykuje parlamentaryzm, kwestionuje zasadność istnienia partii politycznych, podważa etykę niemającą za podstawę zasad dobrobytu własnego narodu. W retoryce 
Balickiego widoczny jest wpływ pozytywizmu Herberta Spencera i koncepcji organicznej społeczności. Oprócz składników ideologii Balickiego autor konstruuje także jego profil biograficzny. Wpływ pozytywizmu jest również widoczny w koncepcjach najważniejszego reprezentanta polskiej myśli narodowej: Romana Dmowskiego autora Myśli nowoczesnego Polaka. Owo dzieło można traktować jako swoisty manifest „nacjonalizmu polskiego”. Włoski autor docenia przenikliwość argumentacji oraz wyrafinowaną strukturę prac Dmowskiego, jak również analizuje podstawowe idee zawarte w dziele opublikowanym w 1903 roku. Część monografii Stasiego poświęcona dziełu Romana Dmowskiego stanowi (można by rzec) swoisty punkt kulminacyjny całej struktury analitycznej pracy, dotyczącej kwestii nacjonalizmu. Jego podstawowe założenie interpretacyjne przedstawione już na pierwszych stronach monografii znajduje w analizie myśli Dmowskiego zasadnicze potwierdzenie. Według Stasiego Dmowski wiąże zasadniczy problem powstawania narodu polskiego z kwestią obecności w społeczeństwie „elementu obcego” (terminu tego używają polscy narodowcy na określenie grupy etnicznej, jaką są Żydzi). „Element” ów definiowany jest jako czynnik zajmujący w owym czasie kluczowe miejsce w strukturze społecznej, „trzon” tak mocno w nim posadowiony, iż - wedle Dmowskiego - nie pozwala on na odbudowanie państwa, a wręcz stanowi zasadniczą przeszkodę w budowaniu polskości jako takiej. Ten ostatni aspekt w myśli Dmowskiego pozostaje szeroko analizowany przez Stasiego - niejako obok pozostałych wykładni idei wiodących dyskursu reprezentanta endecji.

Książka Stasiego stanowi udaną próbę rekonstrukcji procesu narodzin polskiej myśli narodowej, opisania linii argumentacyjnej podejmowanej przez uczestników zdarzeń, a także przedstawienia kontekstu historycznego, prezentację źródeł filozoficznych i kulturowych nurtu oraz jego doktryny. Praca została wydana w prestiżowej mediolańskiej serii wydawnictwa FrancoAngeliego w 2018 roku i stanowi niezbędne narzędzie dla tych włoskich historyków, którzy pragną lepiej zrozumieć korzenie pewnej części historii Polski oraz chcą uchwycić nieoczywiste niuanse jej kultury politycznej.

\section{Bibliografia}

BALICKı Zygmunt (2012): Nasza niezależność duchowa. „Przegląd Narodowy”, nr 3. BALICKI Zygmunt (2008): Parlamentaryzm. Wybòr pism. Red. P. Koryś. Kraków. DMOWSKI Roman (2012): Myśli nowoczesnego Polaka. Wrocław.

DMOWSKI Roman (2013): Kościót, naród i państwo. Wrocław.

KOŁAKOWSKı Leszek (2009): Główne nurty marksizmu. T. 2: Rozwój. Warszawa.

217

Fabrica Litterarum Polono-Italica | 2020, nr 1 (2) 
POPŁAWSKI Jan Ludwik (1998): Wybór pism. Red. T. Kulak. Wrocław.

POPŁAWSKI Jan Ludwik (2012): Naród i polityka. Wybór pism. Red. P. Koryś. Kraków.

SCHRADE Ulrich (2004): Międzywojenna polska myśl narodowa: od patriotyzmu do globalizmu. Kraków.

SowA Jan (2011): Fantomowe ciało króla. Peryferyjne zmagania z nowoczesna forma. Kraków.

STASI Daniele (2018): Le origini del nazionalismo in Polonia. Milano.

WALICKI Andrzej (2009): Naród, nacjonalizm, patriotyzm. Prace wybrane. Kraków.

\section{Abstract \\ La nascita del pensiero nazionale polacco - da una prospettiva italiana}

Nell'articolo è presentato il libro di Daniele Stasi riguardante le origini del nazionalismo polacco. La pubblicazione, apparsa nel 2018 in italiano presso l'editore FrancoAngeli, si initola Le origini del nazionalismo in Polonia. L'autore illustra alcune tesi legate al processo di national building nel periodo precedente alla Grande Spartizione polacca, che rappresenta altresì il termine a quo della sua analisi circa la formazione dell'ideologia connessa al problema della nazione e della rinascita dello Stato Polacco. Termine ad quem del lavoro è costituito dall'edizione di Myśli nowoczesnego Polaka di Roman Dmowski. L'opera di Stasi, basata su ricchi riferimenti bibliografici interdisciplinari, ha come obiettivo colmare una lacuna nella storiografia italiana relativamente alle origini del nazionalismo in Polonia.

Parole chiave: nazionalismo, modernizzazione della Polonia, movimento di massa, Roman Dmowski 